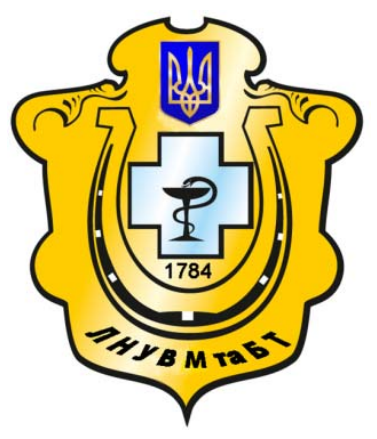

Науковий вісник Львівського національного університету ветеринарної медицини та біотехнологій імені С.3. Гжицького

Scientific Messenger of Lviv National University of Veterinary Medicine and Biotechnologies named after S.Z. Gzhytskyj

doi:10.15421/nvlvet7020

ISSN 2413-5550 print

ISSN 2518-1327 online

$\underline{\text { http://nvlvet.com.ua/ }}$

УДК619: 591.471.35: 598.2

\title{
Особливості будови кісток тазостегнового суглоба птахів, як окремої ланки локомоторного апарата
}

\author{
Н.В. Друзь \\ druznv3011@ukr.net \\ Національний університет біоресурсів і природокористування Украӥни, \\ вул. Героїв Оборони, 15, м. Київ, 03041, Украӥна
}

\begin{abstract}
Дана робота присв'ячена вивченню будови, иляхів формування кісткових структур, що утворюють основу локомоторних органів, а саме тазостегновий суглоб, з'ясування механізмів їх розвитку, бо вони забезпечують їх надійне функиіонування. Вивчення особливостей будови скелета птахів у порівнянні із іншими тваринами дає можливість зрозуміти філогенез, як адаптивний прочес, що складає основу еволючї взагалі.

У статті наведене теоретичне узагальнення особливостей будови тазостегнового суглоба птахів, які характеризуються різними типами біоморфологічнихадаптацій, а саме типом та швидкістю наземного пересування у середовищі існування. Це дозволяє з нових позицій провести аналіз процесів диференціачії та трансформації м'язових та скелетних елементів тазостегнового суглоба птахів, що функціонують та розвиваються під дією різних зовнішніх чинників.

Викладено узагальнені результати оригінального системного морфо-функціонального та морфо-екологічного дослідження кісток тазостегнового суглоба, як основного апарату біпедальної локомоиії класу птахи. Вперше наводиться детальний порівняльний опис скелетних елементівтазостегнового суглоба птахів, щзо супроводжується унікальним історичним оглядом та охоплює більш ніж дві тисячолітній період. Проведено аналіз деяких значущих морфологічних структур, щзо дає ключі до реконструкиії адаптивної еволюиії будь-якої групи птахів.

Ключові слова: птахи, кістки, тазостегновий суглоб, клубова кістка, сіднича кістка, лобкова кістка, стегнова кістка, еволючія, морфологія, локомоція, онтогенез, філогенез.
\end{abstract}

\section{Особенности стоениякостей тазобедренного сустава птиц, как отдельной части локомоторного апарата}

\author{
Н.В. Друзь \\ druz_nv3011@ukr.net \\ Национальный университет биоресурсов и природопользования Украины, \\ ул. Героев Обороны, 15, г. Киев, 03041, Украина
}

\begin{abstract}
Данная работа посвящена изучению строения, путей формирования костных структур, образующих основу локомоторных органов, а именно тазобедренный сустав, выяснение механизмов их развития, так как они обеспечивают их надежное функиионирование. Изучение особенностей строения скелета птии по сравнению с другими животныли дает возможность понять филогенез, как адаптивный процесс, составляет основу эволюиии вообще.

В статье приведено теоретическое обобщение особенностей строения тазобедренного сустава птии, которые характеризуются различными типами биоморфологических адаптаций, а именно типом и скоростью наземного передвижения в среде обитания. Это позволяет с новых позиций провести анализ процессов дифференциации и трансформации мышечных и скелетных элементов тазобедренного сустава птии, функиионирующих и развиваюшихся под действием различных внешних факторов.
\end{abstract}

Citation:

Druz, N.V. (2016). Features of bone structure of birds'hip joint as individual link of locomotor apparatus. Scientific Messenger LNUVMBT named after S.Z. Gzhytskyj, 18, 3(70), 88-90. 
Изложены обобщенные результаты оригинального системного морфо-функционального и морфо-экологического исследования костей тазобедренного сустава, как основного аппарата бипедальной локомоции класса птицьь. Впервье приводится детальное сравнительное описание скелетных элементов тазобедренного сустава птии, сопровождается уникальным историческим обзором и охватывает более двух тысячелетний период. Проведен анализ некоторых значимых морфологических структур, который дает ключ к реконструкции адаптивной эволющии любой группь птиц.

Ключевые слова: птиць, кость, тазобедренныййсустав, повздошняякость, седалищнаякость, лоннаякость, бедреннаякость, эволючия, морфология, локомочия, онтогенез, филогенез.

\title{
Features of bone structure of birds'hip joint as individual link of locomotor apparatus
}

\author{
N.V. Druz \\ nata3011@bigmir.net \\ National university of life and environmental sciences of Ukraine, \\ Heroes of Defense Str., 15, Kiev, 03041, Ukraine
}

This article is dedicated to the study of the structure, ways of formation of bone structures that form the basis of locomotor organs, namely the hip joint, the elucidation of mechanisms of their development, because they provide their reliable functioning. The study of the structural features of the skeleton of birds in comparison to other animals makes it possible to understand the phylogeny as an adaptive process that is the basis of evolution at all.

Theoretical generalization of structural features of birds' hip joint that are characterized by different types of biomorphological adaptations, such as the type and speed of ground movement in the habitat, are presented in the article. This new position allows analyzing the processes of differentiation and transformation of muscles and skeletal elements of birds' hip joint, which are functioning and developing under the influence of various external factors.

The summarized results of the original systematic morpho-functional and morpho-ecological study of hip bones as the main unit of bipedal locomotion of the Class Aves, is given. A detailed comparative description of skeletal elements of birds' hip joint, that accompanied by unique historical overview which covers more than two-thousand-year period, is provided for the first time. The analysis of some significant morphological structures, which gives clues to the reconstruction of adaptive evolution of any group of birds, is given.

Key words: birds, bones, hip joint, ilium, sciatic bone, pubic bone, the femur, evolution, morphology, locomotion, ontogeny, phylogenesis.

\section{Ветуп}

Птахи - це унікальна група тварин, яка останнім часом знаходиться в полі зору сучасних морфологів. Різним способам пересування птахів, належить провідна роль еволюції і широкої адаптивної радіації цієї групи наземних хребетних тварин (Fürbringer, 1888; Gadow and Selenka, 1891). Трубчасті кістки, що утворюють кісткову основу кінцівок птахів, забезпечують стале функціонування локомоторного апарату в умовах, що змінюються статичних і динамічних навантажень 3 певним запасом міцності (Mel'nyk et al., 2012; Mel'nyk and Druz', 2015). Однак, багато аспектів формування кісткових структур в онто- і філогенезі птахів досі залишаються нез'ясованими.

\section{Матеріал і методи досліджень}

Робота виконана на кафедрі анатомії тварин ім. акад. В.Г. Касьяненка НУБіП України. Дослідження проводились на 237 екземплярах, 87 видах, 22 рядів класу птахи. Остеометричні дослідження проводили за допомогою штангенциркуля та метра.

\section{Результати та їх обговорення}

Специфічність тазового поясу птахів полягає в тому, що тазові кістки досить міцно зростаються з поперековими та крижовими кістками, формуючи монолітну кісткову структуру, яка, крім того, що служить захистом внутрішніх органів та місцем фіксації м'язів, є ще й центром качання тіла між тазовими кінцівками (Sych, 1999). Останнє, у свою чергу, має важливе значення для локомоції. Слід зазначити, що лінія центру качання тіла проходить по лінії тазостегнових суглобів, а саме по лінії суглобової западини.

Відносна довжина преацетабулярної частини клубової кістки совоподібних, порівняно з іншими дослідженими птахами, певною мірою менша. Разом 3 тим слід зазначити, що в пірникозо- та буревісникоподібних форма клубової кістки по всьому периметру однакова. У деяких куроподібних (свійський індик) форма клубової кістки має неправильну чотирикутну форму, у більшості папугоподібних - трикутну, а в решти досліджених видів - у вигляді неправильного овалу. Характерною для птахів є різка, з добре вираженим кутом, форма переходу дорсального гребеня клубової кістки у дорсо-латеральний. Ми вважаємо, що зазначені особливості будови клубової кістки обумовлені дією м'язів, що фіксуються на ній.Противертлюг - на нашу думку, ця притаманна птахам структура, забезпечує опору для проксимального кінця стегнової кістки під час локомоції, та обмежує амплітуду рухів у тазостегновому суглобі.

Сіднича кістка у африканського страуса має каудальну сідничу вирізку, що в інших досліджених птахів відповідає чітко вираженому сідничому отвору. Цечітко доводить, що сідничий отвір більшості птахів сформувався з сідничої вирізки за рахунок осифікації прилягаючих сполучно-тканинних структур. Упінгвіно-, пірникозо-, буревіснико-, пелікано-, лелеко-, куро-, голубо-, папуго-, дрімлюго-, серпокрильце- 
та горобцеподібних вона має неправильну чотирикутну форму, у гагаро-, гусе-, журавле- та сивкоподібних прямокутну та неправильну овальну форму у фламінго-, соколо-, сово- та дятлоподібних. Різноманітність форми сідничої кістки, як і однотипність лобкової кістки, знову ж таки може бути пояснено лише дією м'язів, що фіксуються до них.

Сідничо-лобкове вікно у страусо-, нанду- та казуароподібних за рахунок зрощення між собою каудальних частин сідничої та лобкової кісток, є замкнутим. Майже в усіх досліджених видів птахів воно заповнене сухожильною мембраною. Однак у пінгвіно-, деяких лелеко-, більшості яструбо- та куро-, а також деяких журавлеподібнихсідничо-лобкове вікно практично відсутнє. Цечітко підтверджує вище сказану думку про дію функціональних навантажень.

Суглобова западина у деяких гусе- та куроподібних повністю осифікована. Ця осифікація може бути пояснена лише дією підвищених функціональних навантажень $з$ боку маси тіла.

Проксимальна частина стегнової кістки птахів, зокрема шийка, у більшості птахів широка, однак у страусо-, гусе-, соколо- та дятлоподібних вона продовгувата, у нанду-, казуаро-, гагаро-, поганко-, буревіснико-, деяких пелікано-, лелеко-, журавле-, сивко-, голубо-, папуго-, сово-, дрімлюго-, серпокрильце- та горобцеподібних - коротка. Ми вважаємо, що різний ступінь розвитку шийки стегнової кістки птахів обумовлений здатністю до здійснення більшої або меншої амплітуди рухів у тазостегновому суглобі.

Вертлюг стегнової кістки притаманний всім дослідженим птахам, на нашу думку, ступінь розвитку вертлюга стегнової кістки зумовлений дією м'язів, які на ньому фіксуються, а також залежить від статичного кута між стегновою та тазовою кістками, що різне напруження м'язів.

\section{Висновки}

Відмінність форми та відносних розмірів структурних елементів тазостегнового суглоба досліджених видів птахів, обумовлені типом опори та способом біпедальної локомоції, дією функціональних навантажень на ту чи іншу із зазначених ділянок. Закритий суглобовий отвір в суглобовій западині у деяких досліджених видів птахів виникає під час дії функціональних навантажень та суглобовий суглоб під час маніпуляційних рухів.

Перспективи подальших досліджень. Детальний порівняльно-анатомічний опис скелетних елементів, дає можливість зрозуміти процес їх формування та розвитку під дією різних зовнішніх чинників.Виявлення особливостей скелетних елементів птахів, на широкому порівняльно-анатомічному матеріалі, встановлення відмінності форми та розмірів кісток, що формують суглоб, різний ступінь вираженостісідничо-лобкового вікна, осифікація суглобового отвору, форма та розмір сідничного отвору, а також утворення затульного втиснення дозволять зробити вагомий внесок у вирішенні проблем взаємозв'язку між формою, структурою і функцією та дають змогу виявити закономірності становлення i розвитку тазостегнового суглоба птахів.

\section{Бібліографічні посилання}

Mel'nyk, O.P., Druz', N.V., Nikitov, V.P. (2012). Stan i perspektyvy vyvchennja biomorfologii' m'jaziv diljanky stegna ptahiv, Naukovyj visnyk NUBiP Ukrai'ny. 172, 53-58 (in Ukrainian).

Mel'nyk, O.P., Druz', N.V. (2015). Biomorfologichnyj analiz lokomotornogo aparatu tazovoi' kincivky ptahiv, zbirnyk tez NUBiP Ukrai'nую. 56-57 (in Ukrainian).

Sych, V.F. (1999). Morfologija lokomotornogo apparataptic. S.-Peterburg. 101-139 (in Russian).

Fürbringer, M. (1888). Untersuchungenzur Morphologie und Systematik der Vögel. Amsterdam. Jena. 1751.

Gadow, H., Selenka, E. (1891). Bronn's Klassen und Ordnungen des Thier-Reichs. Anatomischer Theil. Leipzig. 1, 6, 1008.

Стаття надійшла до редакиіï 2.10.2016 